Iwona H. Pugacewicz

Warszawa

\title{
Początki bibliotekarstwa publicznego we Francji i świadomości ochrony narodowego dziedzictwa kulturowego a Wielka Rewolucja 1789-1799
}

Ponad trzydzieści lat przed wybuchem Wielkiej Rewolucji Francuskiej Durey de Noinville, uznany mecenas francuskiej książki, pisał o swojej stolicy: „faktem jest, że nie ma na świecie takiego drugiego miasta, które miałoby tyle bibliotek, a liczba książek, tych zgromadzonych w Paryżu jest bardziej znacząca niż wszystkich pozostałych w Europie"1. Wprawdzie w powyższym stwierdzeniu jest wiele dumy i trochę przesady, niemniej Francja epoki ancien régime wydaje się być najpoważniejszym depozytariuszem słowa pisanego.

Jak w całej Europie, tak i tutaj najlepszymi bibliotekami były te, należące do zgromadzeń religijnych. W czasach transmisji rękopiśmiennej tekstu, tj. do końca XV w., większość poważniejszych książnic stanowiły ich własność, świadczącą o prestiżu danego zgromadzenia zgodnie z łacińską sentencją: claustrum sine armario, quasi castrum sine armamentario (klasztor bez księgozbioru jest jak zamek bez zbrojowni). Wraz $\mathrm{z}$ wprowadzeniem druku, kolekcje książkowe duchownych niebywale zaczęły się rozrastać. I tak jak wcześniej ich wykorzystanie było ściśle obwarowane licznymi uwarunkowaniami, których nieprzestrzeganie, jak np. celowe niszczenie dzieł, groziło nawet ekskomuniką, tak wraz z upływem czasu, klasztorne księgozbiory coraz szerzej otwierały swe wrota przed uczonymi oraz wszelkiej maści możnymi czytelnikami, koneserami słowa pisanego i książki, jako wartości samej w sobie, którzy najczęściej wywodzili się z warstw wyższych. Lektura, jako zajęcie elitarne identyfikowała specyficzny stan uprzywilejowany, którego nieco szersze

${ }^{1}$ Cyt. za: G. K. Barnett, Histoire des bibliothéques publiques en France de la Révolution à 1939, Paris 1987 (dalej cyt.: Histoire des bibliothéques...), s. 16. 
granice wyznaczał, poza statusem majątkowym, również i ten intelektualny, przypisywany wybranym.

W Paryżu jedna z najpiękniejszych, powstałych w XII w. bibliotek, należąca do opactwa Świętej Genowefy i licząca w II poł. XVIII w. około 60 tys. woluminów drukowanych i 2 tys. rękopisów, w przeddzień wybuchu rewolucji udostępniła swoją kolekcję nie tylko uczonym, lecz również studentom, poszerzając tym samym krąg tych najniżej uplasowanych w hierarchii społecznej odbiorców.

Inna biblioteka, będąca własnością klasztoru Saint-Germains-desPrés, zgodnie z wolą kardynała Leona Potier des Gesvres, rozpoczęła tego typu ,publiczną"działalność jeszcze przed 1745 r., natomiast od 1789 r. była już czynna codziennie, z wyjątkiem czwartków, ale nadal krąg swoich użytkowników ograniczała do arystokracji, duchowieństwa, naukowców i erudytów, udostępniając im ok. 50 tys. druków i prawie 7 tys. rękopisów.

Podobnie było z biblioteką opactwa Świętego Wiktora, jedną z ważniejszych w stolicy (35 tys. książek i 3 tys. manuskryptów), która od 1652 r. przez trzy dni w tygodniu była otwarta dla analogicznej grupy czytelników z zewnątrz. Zapewne w ślady tychże placówek poszłyby i inne, gdyby nie rok 1789 i słynny szturm na Bastylię.

Zanim przejdziemy do czasów rewolucji, warto odnotować, że podobną tendencję - powszechniejszego udostępniania zbiorów elicie intelektualnej - obserwujemy wśród paryskich bibliotek związanych $\mathrm{z}$ rozlicznymi towarzystwami naukowymi i kolegiami, na czele $\mathrm{z}$ biblioteką Akademii Francuskiej, założoną przez kardynała Richelieu w 1635 r., nie wspominając już o uniwersyteckich. Szczególnie te ostatnie, już w latach siedemdziesiątych XVIII w., funkcjonowały, w pewnym sensie, jako publiczne. I tak np. licząca ponad 30 tys. jednostek biblioteka Sorbony wydała w 1788 r. specjalny dokument, w którym stwierdzało się, że wolny dostęp do księgozbiorów mają wszyscy, którzy „chcą czerpać wiedzę z jej źródeł"2.

Niewątpliwie, w dobie oświeceniowego otwierania się francuskich bibliotek na potrzeby tzw. grand public, naśladowano działania i brano przykład z tych najlepszych. Wobec tego nie można pominąć milczeniem nie zawsze udanych zabiegów takiego właśnie upowszechnienia zbiorów czynionych przez Bibliotekę Królewską, założoną w XIV w. przez Karola V, która już w roku 1537, specjalnym ordonansem wydanym przez króla Franciszka I, zyskała prawo do egzemplarza obowiązkowego.

\footnotetext{
2 Tamże, s. 13.
} 
Wprawdzie, po raz pierwszy została ona otwarta dla możnych czytelników spoza królewskiego otoczenia już w 1692, ale przywilej ów był krótkotrwały. W roku wybuchu rewolucji Biblioteka Królewska, (300 tys. woluminów, 54 pracowników), zaledwie dwa razy w tygodniu udostępniała wybrane fragmenty swoich zbiorów, i tylko tym, którzy legitymowali się stosownym statusem społecznym.

Nie sposób omówić ewolucji wszystkich przedrewolucyjnych książnic, opisać, jak próbowały w miarę racjonalnie otwierać się na potrzeby coraz szerszego gremium odbiorców, często wbrew oczekiwaniom i ku zaskoczeniu tych ostatnich, jeszcze nie przygotowanych do korzystania z zasobów tzw. dziedzictwa literackiego Francji, a jednocześnie nie dopuścić do niszczenia czy innych nadużyć w stosunku do księgozbiorów.

Czy coraz częściej otwierające się książnice miały szanse skutecznego oddziaływania na rzecz powszechnego rozwoju alfabetyzacji i kultury czytelniczej - raczej należy wątpić. Ale debata wokół przyszłych, nowych funkcji kulturowo-oświatowych bibliotek, która na dobre rozgorzała we Francji w połowie XVIII w., była toczona na najwyższych szczeblach. Dyskutowano o tym m.in. na obradach Zgromadzenia Konstytucyjnego, w gronie najświetniejszych polityków, filozofów i erudytów, niejako intuicyjnie, zupełnie nieświadomie, przepowiadając przyszłe, rewolucyjne zmiany $^{3}$. W wieku Woltera, Rousseau i Diderota francuskie społeczeństwo w pierwszej kolejności potrzebowało w miarę powszechnej oświaty, na którą przyszło mu poczekać do czasów ministra François Guizot ${ }^{4}$. Coraz bardziej dostępne zbiory bibliotek prywatnych i kongregacyjnych nie miały szans, wbrew intencjom Condorceta i wielu innych ${ }^{5}$, sprostać wyzwaniom edukacyjnym XVIII w. z uwagi nie tylko na brak stosownej liczby realnie upubliczniających się bibliotek, brak potencjalnych bibliotekarzy-nauczycieli, ale przede wszystkim z uwagi na niedostatek odpowiedniej literatury, lektury, podręczników czy popularnej prasy. Alfabetyzacja najniższych warstw winna stanowić wstęp przygotowujący je do

${ }^{3} \mathrm{H}$. Richard, Des bibliothèques des districts aux bibliothèques municipales, [w:] Histoire des bibliothèques françaises, t. 3: Les bibliothèques de la révolution et du XIXe siècle 1789-1914, sous la direction de D.Varry, Paris 1991 (dalej cyt.: Histoire des bibliothèques françaises...), s. 43.

${ }^{4}$ F. Guizot (1787-1874), francuski historyk, polityk, szczególnie zasłużył się na polu upowszechnienia oświaty zmuszając w latach trzydziestych XIX w. samorządy lokalne do zakładania szkół ludowych, współfinansowanych przez gminy. Więcej zob. Ch. Nique, François Guizot. L'école au service du gouvernement des esprits, Paris 1999, s. 227-238.

${ }^{5}$ Nicolas de Condorcet (1743-1794) był jednym z najżarliwszych orędowników upowszechnienia oświaty i bibliotek wśród ludu, o co nieraz publicznie upominał się jeszcze przed wybuchem Rewolucji 1789 r. Zob. M.-O. Mergnac, C. Brancq, D. Vilret, Les écoliers et leurs metres en France d'autrefois, Paris 2005, s. 16. 
odbioru nowej państwowej, zlaicyzowanej kultury za pośrednictwem tak pomyślanych bibliotek. Próby powierzania im misji rozbudzania i kształtowania powszechnej świadomości narodowej, opartej na wspólnocie języka i literatury, wydawały się być przedwczesne również i z tego powodu, że klasy średnie i niższe nie dostrzegały potrzeby takiego awansu społecznego poprzez edukację czytelniczą. Nie ma, wobec tego, sensu opisywać mimo wszystko odosobnionych przykładów oddziaływania nielicznych upublicznianych jeszcze przed Rewolucją bibliotek nawet na lokalne środowisko, gdyż stanowiły one na mapie Francji najczęściej nieudane eksperymenty. Społeczeństwo, jako całość nie zdążyło się jeszcze odpowiednio przygotować do użytkowania, wykorzystywania tak pomyślanych instytucji publicznych i w zdecydowanej większości nie widziało lub nie rozumiało potrzeby masowego udostępniania zbiorów dla ogółu. Nieunikniony proces dojrzewania do tego typu zmian cywilizacyjno-kulturowych potrzebował czasu. Upublicznienie dóbr narodowych, jakimi było m.in. stopniowe otwieranie bibliotek i upowszechnienie ich zbiorów, w okresie przedrewolucyjnym wynikało bardziej z aspiracji intelektualnych francuskich elit niż realnych potrzeb niedojrzałego do tego społeczeństwa $^{6}$.

Przyczyn tak kreowanej ewolucji, którą za chwileczkę zastąpić miała rewolucja, było wiele, a w jej genezie nie sposób nie wspomnieć o owym przyspieszeniu kulturowo-cywilizacyjnym, wynikającym z dziedzictwa oświecenia, rozwoju osiemnastowiecznej pedagogiki znaczonej upadkiem tradycyjnych autorytetów, rozpowszechnieniem racjonalizmu, a nawet kosmopolityzmu ${ }^{7}$, i nowej polityki kulturalnej państwa, w którą wpisywała się konieczność ujednolicenia ortografii i gramatyki języka francuskiego, jako spójni ideologicznej wspólnego narodu.

O rosnącym zainteresowaniu kształceniem na wszystkich poziomach nauczania (z elementarnym na czele), o dojrzewającej potrzebie nowej, bardziej popularnej lektury, biblioteki czy ludowej czytelni dobitnie świadczy liczba publikacji temu poświęconych. W latach 1760-1791 na temat konieczności alfabetyzacji Francuzów z niższych warstw społecznych, szeroko pojętego nauczania publicznego, w tym roli lektury i konieczności upowszechniania czytelnictwa, wydano aż 161 książek $^{8}$.

${ }^{6}$ B. Bieńkowska, H. Chamerska, Zarys dziejów ksiażki, Warszawa 1987, s. 203-204.

${ }^{7}$ Popularność idei kosmopolitycznych szczególnie widoczna jest w literaturze francuskiej tamtego okresu. Wiecej, zob. G. Lanson, P. Tuffrau, Historia literatury francuskiej $w$ zarysie, Warszawa 1963, s. 283-284.

${ }^{8}$ N. Richter, Les bibliothèques populaires et la lecture ouvrière, [w:] Histoire des bibliothèques françaises..., s. 513-514. 
A wśród nich znalazła się też publikacja niejakiego Louis Philipon de La Madelaine zatytułowana Vues patriotiques sur l'éducation du peuple (Patriotyczne opinie o edukacji ludu), który ośmielił się na kilka lat przed rewolucją zaproponować np. sieć czytelni młodzieżowych, które wprawdzie działałyby tylko zimą, ażeby poza potrzebami duchowymi zabezpieczyc i te zdrowotne, ale za to we wszystkich miastach i wsiach, wspierając tym samym ludową oświatę 9 . Takie i tym podobne, na razie pozostające jedynie na papierze, pomysły na upublicznienie bibliotek ${ }^{10}$ rozpalały wyobraźnię przyszłych rewolucjonistów i polityków.

$\mathrm{W}$ epoce oświecenia pojawiły się też pierwsze zwiastuny bibliotek publicznych z prawdziwego zdarzenia, to znaczy tworzonych w pierwszej kolejności z myślą o podniesieniu kultury i zapewnieniu godnej rozrywki całej lokalnej społeczności, w tym tzw. stanowi trzeciemu, z pominięciem lub usunięciem na plan drugi potrzeb intelektualno-naukowych elit ${ }^{11}$. Powtarzany schemat ich „lokacji” był taki oto: możny bibliofil, przejęty oświeceniowymi ideami utylitaryzmu społecznego, czynił donację np. na rzecz miasta, parafii czy towarzystwa naukowego z zastrzeżeniem, że jego kolekcja ma być ogólnie dostępna, jak w przypadku Antoin'a Moriau'a, który przekazał swoje ponad czternastotysięczne zbiory paryskiemu Hôtel de Ville, lub markiza de Méjanesa z Aix-en-Provance, który z kolei ofiarował w testamencie swoją, liczącą ponad 80 tys. jednostek, bibliotekę miastu ${ }^{12}$. Oba księgozbiory charakteryzowało znaczne nagromadzenie literatury pięknej, o charakterze mniej naukowym, bardziej kulturalno-rozrywkowym. Nieliczne opracowania mówią o około 37 prowincjonalnych książnicach pełniących, jeszcze przed rewolucją, funkcje tak rozumianych bibliotek publicznych ${ }^{13}$ oraz wspominają o namiastkach pierwszych przedrewolucyjnych czytelni ludowych, tzw. cabinets de lecture, pojawiających się w największych aglomeracjach, takich jak Paryż, Bordeaux, Lyon i w innych miastach ${ }^{14}$.

${ }^{9}$ Tamże, s. 514

${ }^{10}$ Więcej: F. Barbier, Livres, lecteurs, lectures, [w:] Histoire des bibliothèques françaises..., s. 578-623.

${ }^{11}$ Wydana w roku 1789 broszurka Emmanuel-Joseph'a Sieyès, Czym jest stan trzeci? (Qu'est-ce que le tiers état?), odnosząca się do ponad 95\% ludności Królestwa Francji, stała się prawdziwym manifestem rewolucji, krystalizującym poglądy opisywanej warstwy społecznej.

${ }^{12}$ G.K. Barnett, Histoire des bibliothéques..., s. 15-16.

${ }^{13}$ M. Wierzbicka, Biblioteki publiczne we Francji, [w:] Zeszyty przektadów. Bibliotekarstwo we Francji, na prawach rękopisu, Biblioteka Narodowa, Instytut Książki i Czytelnictwa, 1959, nr 4/8, s. 11.

${ }^{14}$ K. Maleczyńska, Zarys historii bibliotek od XV do XVIII wieku, Wrocław 1976, s. 65. 
„Modernizacja utorowała sobie dwie ścieżki: anglo-amerykańską ewolucyjną, gdzie wolność jednostki broniona jest skutecznie przed roszczeniami władzy dzięki mądrości tradycji, doświadczeniu i codziennej praktyce, oraz francuską - wstrząsową, rewolucyjną, dokonującą modernizacji poprzez radykalną regenerację ideologiczną (...), poprzez 'uśmiercanie tyrana' i przejęcie władzy przez lud"15. Historia francuskiego bibliotekarstwa publicznego, wpisana w ów drugi model modernizacji społeczeństwa i państwa wydaje się być ważnym przyczynkiem do narodzin takich pojęć jak obywatelskość i jedność narodowa, które, z kolei, sekundują powstawaniu bibliotek publicznych będących na usługach państwa.

Idea upublicznienia bardziej lub mniej izolowanych, prywatnych bądź instytucjonalnych książnic, zawierała w sobie dwie nowe, istotne z rewolucyjnego punktu widzenia przesłanki, które miały przyczynić się do budowy jednolitego, nowoczesnego narodu francuskiego na zasadzie państwa obywatelskiego. Pierwszą z nich była wzrastająca świadomość wspólnego dziedzictwa narodowego w postaci kultury niematerialnej, zapisanej myśli, idei, języka, historii, tradycji i całego dziejopisarstwa francuskiego. Drugą stanowiła potrzebę nadania temuż dopiero definiowanemu patrymonium waloru wspólnotowości oraz powszechności zgodnie z wypracowaną zasadą: równości, wolności i braterstwa.

Bez żadnej wątpliwości należy stwierdzić, że to właśnie Wielka Rewolucja Francuska dokonała najpoważniejszego kroku na drodze ku upublicznieniu wszystkich, bez wyjątku, rodzajów bibliotek, ale czyniła to przede wszystkim w imię wspólnotowych wartości narodowych. Dostrzeżenie potrzeby i głośne żądanie udostępnienia księgozbiorów dla warstw niższych było niejako historyczną prowokacją, mającą służyć zmianie paradygmatu francuskiej tożsamości narodowej, do niedawna identyfikowanej tylko z królem i jego najbliższym otoczeniem, tj. ze szlachtą i klerem od symbolicznego roku 1789 rozciągniętej na wszystkie stany, na czele z tym najniższym, któremu należało uzmysłowić francuski rodowód, czyli wspólną historię i przynależność do jednego organizmu państwowego. Rewolucja rozpoczęła nie tylko nowe konstruowanie patriotyzmu, wbudowane w ideę wspólnego państwa zwanego republika, ale też uświadomiła jej twórcom istnienie bardziej radykalnej jego odmiany,

15 J. Kowalski, A. i M. Loba, J. Prokop, Dzieje kultury francuskiej, Warszawa 2005, s. 390 . 
jaką był nacjonalizm, wyrażający się potępieniem dotychczasowego ustroju feudalnego i odpowiadającej z jego utrzymanie klasy rządzącej.

Nowy paradygmat wymagał nowych zdemokratyzowanych instytucji społecznych, takich chociażby jak otwarte muzea, biblioteki, wystawy, ogrody, parki publiczne etc.

Zaledwie w cztery miesiące po wybuchu rewolucji Zgromadzenie Konstytucyjne wydało dekret, na mocy którego wszelkie dobra zarówno ruchome, jak i nieruchome, należące do duchowieństwa przechodzą na własność narodu. Tak więc tysiące gromadzonych od wieków cennych woluminów zostało prawnie skonfiskowane. Kolejny dokument z roku 1792, o analogicznej treści, przejmował na własność państwa majątki zbiegów i emigrantów. I wreszcie trzeci akt, wydany w roku 1793, konfiskował biblioteki wszelkich towarzystw naukowych i akademii, na czele z tą najsłynniejszą, założoną przez kardynała Richelieu w 1635 r., jako pierwszą w Europie ${ }^{16}$.

Sporządzanie stosownych zapisów prawnych w celu nowego upodmiotowienia zabranych dóbr jako własności całego francuskiego narodu, posiadającego wspólne dziedzictwo w postaci piśmiennictwa zgromadzonego i udostępnionego w planowanych publicznych bibliotekach i czytelniach ludowych, to zaledwie początek swego rodzaju ideologicznej nacjonalizacji służącej budowie państwa narodowego. Kolejnymi, zdecydowanie trudniejszymi do realizacji etapami będą: (1.) faktyczne przejęcie/odebranie owych setek tysięcy woluminów od dawnych właścicieli; (2.) ich ocenzurowanie, to znaczy podział na dwie podstawowe grupy: literaturę zgodną $\mathrm{z}$ duchem rewolucji oraz literaturę stanowiącą podstawy starego ustroju, czyli nienadającą się do kształtowania nowego, lepszego wzorca obywatelskiego; (3.) zabezpieczenie i konserwacja jedynie owych „prawomyślnych” dzieł, pozbycie się pozostałych; (4.) ponowne skatalogowanie, a raczej zastąpienie dotychczasowych poszczególnych spisów i niekompletnych inwentarzy jednym zwartym katalogiem nazwanym, zgodnie z duchem rewolucji, Indeksem Rozumu (Index de la Raison $)^{17}$; i wreszcie (5.) sprawiedliwy rozdział tak wyselekcjonowanych i zinwentaryzowanych ksiąg pomiędzy nowo powoływane zalążki bibliotek i zakładów publicznych (uczelnie, szkoły, czytelnie, internaty, etc.).

${ }^{16}$ D. Palliers, Les bibliothèques, Paris 2006, s. 35.

${ }^{17}$ K. Maleczyńska, Zarys historii..., s. 71. 
Powróćmy do etapu pierwszego - przejmowania różnego rodzaju księgozbiorów. W zasadzie od końca roku 1789 i przez cały następny, zarówno na poziomie centrum, jak i na prowincjach, opracowywano szczególowe zasady konfiskaty bibliotek duchownych. Ostatecznie zobowiązano wspólnoty religijne do sporządzenia raportów na temat stanu ich posiadania, weryfikację dotychczas istniejących katalogów pod względem ubytków i przekazanie tegoż wszystkiego władzom departamentalnym, a ponadto wysłanie drugiego egzemplarza tak sporządzonej dokumentacji do tzw. Komitetu Instrukcji Publicznych (Comités d'instruction publique) w Paryżu. Za transport i przechowywanie przejętych książek i innych dóbr kościelnych (obrazy, ryciny, mapy, medale, numizmaty etc.) odpowiadać miały specjalnie tworzone w tym celu komisje miejskie, powoływane tam, gdzie planowano utworzenie docelowych depozytów, tzw. dépôt littéraire, czyli magazynów „świeżo” skonfiskowanej literatury.

Cała procedura konfiskacyjno-inwentaryzacyjna była dosyć niejasna, a dotychczasowi właściciele bibliotek robili wszystko, ażeby dodatkowo jeszcze ją utrudnić. Wzorem paryskiego przeora karmelitów, Jacquesa Iniberta, który zadeklarował posiadanie zaledwie 1834 woluminów, a faktycznie miał ich ponad 10 tys. $^{18}$, powszechnie zaniżano liczbę książek. Potajemnie wywożono je za granicę, przekazywano zaufanym, chowano po piwnicach, strychach, a nawet zakopywano pod ziemią w drewnianych szafach czy skrzyniach, licząc na rychly koniec rewolucji19. $\mathrm{Z}$ drugiej strony niedomogi organizacyjne i zwłoka ze strony nowych władz również powodowały bałagan i opóźnienia w przejmowaniu bibliotek. Niewłaściwie strzeżone i nieopieczętowane we właściwym czasie, a więc ogólnie dostępne zbiory, opuszczone, otwarte kościoły i opactwa kusiły złodziei. W niektórych prowincjach, jak np. w Seine-et-Oise czy Seine-Inférieure, zdarzało się, że to Rada Departamentalna (nowa, rewolucyjna władza lokalna), nie czekając na polecenia z Paryża, brała sama na siebie trud transportu i zabezpieczenia najcenniejszych dzieł sztuki i książek, znajdując na ich składowanie w miarę bezpieczne miejsca, jak np. we wspomnianym przypadku - prefektura miejska ${ }^{20}$. Były to jednak nieliczne wyjątki. Stan powszechnie panującego rozgardiaszu i nieporządku, pośpiechu, wieloznaczności decyzji przyczynił się do ogromnych, dzisiaj już niemożliwych do dokładnego oszacowania, strat.

${ }^{18}$ G.K. Barnett, Histoire des bibliothèques ..., s. 18.

${ }^{19}$ Więcej przykładów ukazujących utrudnianie konfiskaty zbiorów, zob.: D. Varry, Les confiscations révolutionnaires, [w:] Histoire des bibliothèques françaises..., s. 14.

${ }^{20}$ G.K. Barnett, Histoire des bibliothèques..., s. 19. 
Jeśli idzie o politykę i działania administracyjno-państwowe wobec konfiskowanych bibliotek, rozpoczęto je od powołania na najwyższych szczeblach stosownych ciał kolegialnych, które miały czuwać nad całością operacji przejmowania ich na rzecz Rewolucji. Poza wyżej wspomnianym Komitetem Instrukcji Publicznych, warto odnotować powstanie tzw. Komitetów Połączonych (Comités-Réunis), sześcioosobowego ciała powołanego przez Zgromadzenie Narodowe pod koniec 1790 r., składającego się z trzech członków - prawych obywateli, wcześniej należących do tzw. Comité ecclesiastique (Komitet ds. ruchomości pokościelnych) i trzech do Comité d' aliénation des biens nationaux (Komitet ds. sprzedaży dóbr narodowych), których wspólnym celem była ocena, jakie książki ostatecznie przechodzą na własność państwa, a jakie przeznaczyć należy do sprzedaży lub rozdysponowania w jakikolwiek inny sposób. Oba komitety pracowały również nad pozyskaniem i przekazaniem najcenniejszych dzieł do nowopowołanej Biblioteki Narodowej, dawnej Królewskiej. Ponadto ustalały szczegółowe procedury samych przejęć i sporządzały dziesiątki wykazów ksiąg szkodliwych, zakazanych, przeznaczonych do zniszczenia. Następnie zajmowały się sprawiedliwym rozprowadzeniem tych wyselekcjonowanych - prawomyślnych po wszystkich departamentach i dystryktach ${ }^{21}$, zasilając tym samym biblioteki publiczne nowej Francji i wreszcie, miały czuwać nad sporządzeniem jednego, centralnego katalogu tychże nabytków, najpierw dla wszystkich bibliotek Paryża, a później całego kraju.

Jednym z pierwszych działań Komitetów Połączonych było powołanie w stolicy eksperckiego zespołu składającego się z bibliografów i najwyższej klasy bibliotekarzy, których zadanie polegało na bieżącym wspieraniu strategicznych decyzji polityków poprzez np. doradzanie, gdzie zakładać owe dépôt. Ponadto mieli poświęcić się pracy nad jednym, wspólnym inwentarzem wszystkich zbiorów bibliotecznych zgromadzonych w stolicy oraz nadzorować przejęcia kolejnych kolekcji zgromadzeń duchownych i prywatnych na terytorium całego kraju pod kątem wyselekcjonowania i przechwycenia najcenniejszych pereł francuskiej literatury na rzecz bibliotek Paryża, z Biblioteką Narodową na czele. Z uwagi na

${ }^{21}$ Tuż po wybuchu rewolucji Zgromadzenie Konstytucyjne zajęło się zmianą mapy administracyjnej Francji w imię tworzenia jednolitego nowoczesnego państwa. Powołano do życia 83 departamenty, które zostały podzielone na dystrykty, a te z kolei na komuny (w miejsce dawnych parafii). Zob.: D. Nordman, M. Ozouf-Marignier, Atlas de la Révolution française. Le territoire, réalités et représentation, [w:] Mappe Monde, 1989, t. 4, s. 34-37 oraz J. Kowalski, A. i M. Loba, J. Prokop, Dzieje kultury francuskiej..., s. 401 i 405. 
nawał różnorodnych prac, równocześnie z ową grupą ekspertów, ale w innym celu, bo do wyceny wartości poszczególnych księgozbiorów, bądź jedynie najcenniejszych egzemplarzy, powołana została tzw. Komisja Uczonych (Commission des savants), która miała francuskie bogactwo intelektualne mierzyć wartością pieniądza. Ostatecznie wszystkie wymienione wyżej organizmy połączyły się w jedną całość i utworzyły już w 1790 r. tzw. Komitet Czterech Narodów (Comité des Qatres-Nations), rok później przemianowany na Komisję do Spraw Pomników (Commission des monuments), której głównym zadaniem była ochrona nowo nabytych księgozbiorów, a także wszelkich innych obiektów ruchomych o charakterze muzealnym oraz zabezpieczenie ich przed rozproszeniem i zniszczeniem. Z czasem do pierwotnego składu komisji dokooptowano dodatkowo dwunastu ekspertów z różnych dziedzin (poza wspomnianymi wyżej specjalistami od bibliotek i wszelkiego typu archiwaliów zaproszono m.in. numizmatyków, archeologów, paleontologów, znawców sztuki etc.), którzy mieli pracować nad zdefiniowaniem szeroko rozumianego francuskiego dziedzictwa narodowego ${ }^{22}$. W jej składzie bardzo ważną funkcję pełniła sekcja bibliograficzna, której przypadło w udziale karkołomne wręcz zadanie stworzenia centralnego katalogu całości piśmiennictwa francuskiego (o czym niżej). Jej też autorstwa są liczne instrukcje dotyczące nowej organizacji, klasyfikowania i katalogowania kolejno przejmowanych bibliotek. To właśnie owa Komisja, w imieniu władz państwowych, prowadziła ożywioną korespondencję z komitetami lokalnymi, w miarę sprawnie kierując do połowy lat dziewięćdziesiątych ich pracami z zakresu przejmowania i składowania skonfiskowanych dóbr, udzielając setek porad i różnego rodzaju pomocy w inwentaryzacji książek, manuskryptów, najróżniejszych dokumentów, etc. Nieraz udawało się jej też w ostatniej chwili wstrzymywać wiele nieprawomocnych wyprzedaży, zarówno w stolicy, jak i na prowincjach. I tak na przykład w departamencie la Seine-Inférieure, dzięki szybkiej interwencji agentów z Centralnej Komisji, zabroniono publicznej wyprzedaży ponad 100 tys. woluminów, w tym wielu bezcennych starodruków ${ }^{23}$. Jej członkowie nie szczędzili wysiłku w celach zabezpieczania wartościowych rękopisów, ratowania rozproszonych po kościołach i pozostawianych na łaskę losu zabytków sztuki sakralnej. Wizytowali rezydencje książąt i biskupów, klasztory i opactwa, ażeby powstrzymać bezmyślny wandalizm

${ }^{22} \mathrm{P}$. Riberette, De la Commission des monuments au Conseil de conservation, [w:] Histoire des bibliothèques françaises..., s. 33 .

${ }^{23}$ G. K. Barnett, Histoire des bibliothèques..., s.19. 
czy celową destrukcję, i co najważniejsze, po wszystkich dystrykrach Francji zakładali specjalne magazyny, wspomniane wyżej dépôt littéraire, w celu nie tylko składowania, ale i stosownej ochrony sukcesywnie przejmowanego mienia.

Owe depozyty biblioteczne (w bardziej dosłownym tłumaczeniu: „składnice literatury”), które miały służyć gromadzeniu skonfiskowanych z całej okolicy księgozbiorów, w większości przypadków starano się sytuować w miarę centralnie, w dużych miastach, a najczęściej w stolicach poszczególnych prowincji, ażeby były łatwo dostępne i mogły w niedalekiej przyszłości służyć nie tylko wybranym lecz ogółowi społeczności. Często na ich magazynowanie wybierano opuszczone pomieszczenia poklasztorne, czy pozostawiane przez uciekającą przed gilotyną arystokrację i szlachtę rezydencje, a więc miejsca powszechnie znane i do niedawna szanowane. To tam zwożono taczkami, furami, drezynami, rzadko kiedy karetami (bo te zdążono już zniszczyć, jako symbol znienawidzonej arystokracji), transportowano w koszach na opał, w wiadrach na wodę tysiące konfiskowanych woluminów. Zanim jednak podejmowano ostateczne decyzje o wyborze docelowej składnicy, często, jak w przypadku miasta Mâcon i wielu innych, kilkakrotnie przenoszono zbiory z miejsca na miejsce, nie mogąc się zdecydować na to najlepsze, tracąc przy tym cenny czas i, co gorsza, znaczną część samych księgozbiorów ${ }^{24}$.

Niestety, w ferworze tych wszystkich działań organizacyjno-transportowych zabrakło miejsca na rzecz najważniejszą, na stosowną troskę i szacunek wobec rekwirowanego mienia - wszak należało ono do znienawidzonych warstw. Oto jak obywatel Bévalet, odpowiedzialny za dépôt litteraire $\mathrm{w}$ mieście Belfort, opisywał jeden $\mathrm{z}$ takich transportów:

Ażeby dać Panu wyobrażenie, Panie Prefekcie, proszę sobie wyobrazić nieregularne stosy ponad 10000 książek wszelkiego formatu i grubości wyrzucane w nieładzie z koszy na środek zupełnie pustej sali (...). Proszę sobie wyobrazić, że ponad połowa $\mathrm{z}$ tych książek wywiezionych od kapucynów i franciszkanów z Thanu, jechała do mnie w straszliwej ulewie, na odkrytych wozach węglowych, spakowane, wrzucone byle jak, zupełnie przemoczone, śmierdzące, prawie zgniłe... ${ }^{25}$.

Konfiskowane często w pośpiechu i pod presją rewolucyjnych emocji zbiory nierzadko były poniewierane, traktowane po macoszemu, tak jak w powyższym opisie, i niestety, nie powodowało to specjalnych wyrzutów

24 Tamże, s.23.

${ }^{25}$ Cyt za: D.Varry, Aux origines de la bibliothèque publique de Belfort, „Bulletin de la Societe belfortaine d'emulation", 1988, s. 150-159. 
sumienia w sercach przedstawicieli Stanu Trzeciego, z myślą o których były wszak przejmowane. W innych wspomnieniach z epoki czytamy: „straż narodowa, zobowiązana do zabezpieczania i pilnowania państwowej własności, często bez żadnych skrupułów wyrywała kartki, ażeby podpalić fajkę, czy dorzucić do ognia, a pergaminowe okładki używano do wyrobu woreczków na proch" 26 .

Nie było też ani czasu, ani środków na to, ażeby chociaż w najprostszy sposób oznaczać proweniencję coraz to nowych, zrzucanych na wspólne stosy transportów, a przecież do tych pokościelnych wkrótce dołączyły konfiskowane kolekcje emigrantów, skazańców politycznych, a następnie towarzystw naukowych i akademii. Piętrzące się góry książek były na tyle przemieszane, że nawet te nieliczne towarzyszące poszczególnym zbiorom spisy, skrupulatnie przekazywane urzędnikom sprawującym pieczę nad dépôt littéraire, na nic się nie zdawały. Zbyt optymistycznie już w 1789 r. zakładano, że w niedalekiej przyszłości nastąpi ich ponowne i całościowe skatalogowanie. Najstarszy zapewne inwentarz nowoprzejętych księgozbiorów, jakim dysponują dzisiejsi historycy i bibliolodzy francuscy, to niekompletny spis, powstały 23 lutego $1791 \mathrm{r}$. W początkach drugiego roku Rewolucji, w składnicach 83 departamentów zgromadzono 4168439 książek, 25973 rękopisy, co stanowiło łącznie 4194412 jednostek $^{27}$.

Jak to zwykle bywa, bardzo wiele zależało od rzetelności ludzi powołanych do nadzoru, organizacji i opieki nad owymi depozytami. Niektórym regionom udawało się zatrudnić kompetentnych bibliotekarzy, jak na przykład w Tuluzie, w której skonfiskowanymi zbiorami zajmował się znany pisarz, dziennikarz, autor Nécrologe des hommes célèbres de France, Jean Castilhon ${ }^{28}$. W Sèvres, z kolei, dwaj dawni kanonicy: Nicolas Liboron-Villers i Ignace Maugin Degautièr zorganizowali skladnicę w lokalnym collège, wykazując przy tym niebywałą wręcz troskę o inwentaryzację nowych zbiorów ${ }^{29}$. Większość jednak miast miała z tym wielkie kłopoty, gdyż rewolucja skutecznie wypłoszyła znaczną część świeckich mecenasów i znawców przedmiotu oraz naukową elitę duchownych za granicę. Niewątpliwie wyjątkiem pod tym względem na mapie Francji

${ }^{26}$ G.K. Barnett, Histoire des bibliothèques..., s. 20.

$27 \mathrm{O}$ różnego rodzaju lukach w pierwszych szacunkach skonfiskowanych księgozbiorów i o dwóch spisach (z 23 lutego 1791 i 30 września 1791) zob: D.Varry, Les confiscations révolutionaires..., s. 18-23.

${ }^{28}$ E.-L. de Lamothe-Langon, A. du Mege, J. T. Laurent-Goss, Biographie Toulousaine, ou Dictionnaire historique des personnage, Paris 1823, vol. 1, s. 109.

${ }^{29}$ G.K. Barnett, Histoire des bibliothèques..., s. 18. 
był Paryż. Tutaj składem 793871 druków i 14249 manuskryptów (dane z 23 lutego 1791 r. $)^{30}$, porządkowaniem, katalogowaniem pozyskanych coraz to nowych księgozbiorów, kierował jeden z najświetniejszych ówczesnych bibliotekarzy-rewolucjonistów, Hubert-Pascal Ameilhon ${ }^{31}$. Wprawdzie zarzucano mu celową destrukcję dokumentów i książek należących do znienawidzonych dwóch pierwszych stanów, prawda jest jednak taka, że to dzięki niemu udało się uratować przed dewastacją biblioteki: Sorbony, Châtelet, Saint-Victor, kolekcje słynnego chemika Antoine'a Lavoisiera zgilotynowanego w 1794, księgozbiór adwokata ostatniego króla Francji Guillaume'a-Chrétiena de Lamoignon de Malesherbes czy zbiór markiza d'Ormessona, dawnego generalnego kontrolera finansów Ludwika XVI ${ }^{32}$. H.-P. Ameilhonowi zawdzięcza też stolica skatalogowanie dwudziestu pięciu potężnych depozytów, które stanowiły początek przyszłych najświetniejszych paryskich bibliotek publicznych. Warto sobie uświadomić, że już w końcu owego drugiego roku rewolucji, tylko w składnicach samego Paryża zgromadzono ponad milion książek, a średnio w jednym depozycie znajdowało się ok. kilkunastu tysięcy jednostek, ale bywały i takie, jak ten na ulicy Saint-Honoré, który liczył ok. 130 tys. woluminów czy Saint-Louis-la-Culture - 70 tys. woluminów.

Zanim, zgodnie z nowym kalendarzem Rewolucji, w dniu 8 pluviôse II roku (27 stycznia 1794 r.) ujrzał światło dzienne słynny dekret nakazujący założenie biblioteki publicznej w każdym nowym okręgu administracyjnym Francji, czyli w każdym dystrykcie ${ }^{33}$, wiele przedrewolucyjnych książnic, tych o charakterze publicznym, jak i tych spontanicznie powstających na miejscu dawnych bibliotek kościelnych czy prywatnych zabiegało o przejęcie na własność dépôt littéraire, lub przynajmniej jak największej liczby książek tam zgromadzonych, właśnie w celu uruchomienia lub podtrzymania działalności swojej własnej biblioteki. Administracja lokalna miała świadomość ważności nowych, tworzonych na bazie skonfiskowanych dóbr instytucji, nierzadko dofinansowywanych

${ }^{30}$ D. Varry, Les confiscations révolutionaires...

${ }^{31}$ Hubert-Pascal Ameilhon (1730-1811). Po skończeniu studiów na paryskim uniwersytecie, zgodnie z wolą rodziny, wstąpił w stan kapłański; przed 1789 r. zajmował się głównie twórczością literacką. Gdy tylko rozbrzmiały pierwsze salwy rewolucji - wstąpił w jej szeregi. Pełnił najwyższe funkcje we wszystkich istotnych komisjach i komitetach decydujących o losach bibliotek francuskich.

${ }^{32} \mathrm{H}$. Dufrense, Érudition et esprit public au XVIIIe siècle. Le bibliothécaire Hubert-Pascal Ameilhon (1730-1811), Paris 1962.

${ }^{33}$ Więcej zob: przyp. 18. 
przez państwo, i często sama zabiegała o zaopatrzenie ich w jak najlepsze zbiory. I tak, na przykład urzędnicy z departamentu Maine-et-Loire zwrócili się w dniu 3 października 1792 r. z prośbą do Konwentu o wyrażenie specjalnej zgody na zebranie wszystkich wartościowych, nadal niezagospodarowanych przez nikogo, a rozproszonych po całej okolicy książek, podkreślając przy okazji wyjątkową rolę tak pomyślanej biblioteki i stosownie dobranej lektury, bez której ich zdaniem, i obecna i wszelkie kolejne rewolucje nie powiodłyby się, gdyż ,jedynie dobre książki mogą jej zapewnić trwały sukces i sławę. (...) Nadejdzie taki słodki czas, kiedy poprzez lekturę Platona, Sidney'a i Rousseau wzmocni się ona w miłości dobrych praw i w nienawiści wobec tyranów"34.

Podobne perswazyjne zabiegi o pozyskanie zbiorów na potrzeby prowincjonalnych książnic czyniły biblioteki Dijon, Besançon, Lille i wielu innych miast ${ }^{35}$. Procedura z 1793 r. przewidywała, że powołani w tym celu komisarze będą weryfikować nie tylko poprawność sporządzanych po poszczególnych dystryktach katalogów przejmowanych pozycji, ale przede wszystkim sprawdzać miejsca wybrane na posadowienie nowych depozytów. W praktyce sprowadzało się to do akceptowania przez komisarzy decyzji lokalnych gremiów i wysyłania specjalnych rekomendacji z Paryża, w celu przemianowania dotychczasowych dépôts littéraires na nowe, prowincjonalne biblioteki ${ }^{36}$. Wraz z krystalizowaniem się na francuskiej mapie w miarę regularnej sieci owych składnic, postrzeganych jako źródła przyszłych obywatelskich książnic, ustalono, jak się okazało, na wiele lat, niebywale trwałe siedziby współczesnego nam zrębu najważniejszych francuskich bibliotek publicznych. W wielu przypadkach ich dawna przedrewolucyjna lokalizacja, powracała do łask po chwilowym eksodusie konfiskowanych zbiorów, przewożonych z miejsca na miejsce, od jednego do drugiego składu, ażeby powrócić w dawne miejsce. Bardzo rzadko, przede wszystkim z braku stosownych funduszy decydowano się na budowę nowych książnic od podstaw, częściej organizowano owe rewolucyjne biblioteki w nowych, np. opuszczonych przez zbiegłych rojalistów budynkach ${ }^{37}$.

${ }^{34}$ D. Varry, «Il faut que les lumières arrivent par torrents». La Révolution française et la création des bibliothèques publiques: projets et réalités - http://bbf.enssib.fr/consulter/bbf1989-02-0160-010 [24 XII 2012].

${ }^{35} \mathrm{H}$. Richard, Des bibliothèques des districts aux bibliothèques municipales, [w:] Histoire des bibliothèques françaises..., s. 43-44.

${ }^{36} \mathrm{~K}$. Barnett, Histoire des bibliothèques ..., s. 34.

${ }^{37}$ Więcej na temat poszczególnych siedzib rewolucyjnych bibliotek zob.: K. Barnett, Histoire des bibliothèques..., s. 56-70. 
Z czasem wzrastała też presja lokalna na utrzymanie i maksymalne wykorzystanie skonfiskowanych księgozbiorów w swoim, regionalnym posiadaniu. Wspomniany dekret z 27 stycznia 1794 r., konstytuujący pierwszą sieć publicznych bibliotek w porewolucyjnej Francji, miał też na celu ochronę owego lokalnego dziedzictwa piśmienniczego przed sekwestrami Paryża. Nie pomniejszając w żadnym wypadku wagi powyższego zapisu legislacyjnego, sankcjonującego pierwszą sieć bibliotek publicznych, należy pamiętać, że nie poszły za nim żadne poważniejsze zobowiązania państwowe, dotyczące chociażby finansów, czy wsparcia merytorycznego nowych instytucji. Natomiast wymagano od nich opracowania kompletnego inwentarza przejętych i posiadanych zbiorów, jako warunku sine qua non do zatwierdzenia tak pomyślanej departamentalnej czy dystryktowej biblioteki. Ów inwentarz, sporządzony w dwóch egzemplarzach, miał być zredagowany według zasad i w formie ściśle określonej przez poniżej opisane Biuro do Spraw Bibliografii. A jeden z jego egzemplarzy winien posłużyć tworzeniu centralnego katalogu Francji.

$\mathrm{Na}$ temat konieczności tworzenia bibliotek publicznych $\mathrm{z}$ myślą o wszystkich obywatelach młodej Republiki, na czele ze Stanem Trzecim, zdania były podzielone. W momencie pierwszych konfiskat nikt nie miał ani pojęcia, ani wyobrażenia o ich przyszłym przeznaczeniu. Dopiero później, w początku roku dziewięćdziesiątego, rozpoczęła się dyskusja nad „upublicznieniem” zbiorów. I tu głosy były podzielone. Tak jak francuski generał Charles Leclerc próbował przekonać Zgromadzenie Narodowe, że biblioteki i ich zasoby winny służyć władzy i zapewniać jej ekskluzywną wiedzę, tak uwiedzeni przez jakobińskiego proboszcza Jacques Michel Coupé deputowani, którym ten ostatni powtarzał przy każdej okazji, że to właśnie publiczne książnice mogą stać się prawdziwą obywatelską szkołą Rewolucji, ostatecznie jemu uwierzyli i poparli ów słynny dekret z 27 stycznia $^{38}$.

W zamyśle większości najważniejszych polityków i rewolucyjnych działaczy, jak i tych przerastających swoje czasy, typu Charles-Maurice de Talleyrand ${ }^{39}$, podstawową funkcją nowych bibliotek miała być: po pierwsze edukacja obywatelska i równy do niej dostęp, niezależnie od regionu, wieku, płci; po drugie zaś ochrona i udostępnienie całemu narodowi francuskiego dziedzictwa kulturowego zapisanego na kartach literatury ${ }^{40}$. I to właśnie w czasach rewolucji narodziła się koncepcja sze-

\footnotetext{
${ }^{38} \mathrm{H}$. Richard, Des bibliothequèques des districts au bibliothèques municipales, [w:] Histoire des bibliothèques françaises..., s. 43-44.

${ }^{39}$ R. Harris, Talleyrand: zdrajca i zbawca Francji, Warszawa 2008, passim.

40 Anne-Marie Bertrand, Les bibliothèques, Paris 2004, s. 19.
} 
roko rozumianego francuskiego dziedzictwa narodowego, a do pogłębionego zrozumienia tejże idei, niestety, w ważny sposób przyczynił się wandalizm i niewyobrażalne wręcz straty z lat $1789-1896^{41}$.

Stopniowo, z rewolucyjnej zawieruchy wyłaniała się pierwszy zarys mapy publicznych książnic Francji, tych tworzonych spontanicznie i tych powoływanych z urzędu. Czy ważniejszym powodem ich powstania była potrzeba zapanowania i uporządkowania całego ówczesnego bibliotecznego zamętu, czy bardziej ważyły czynniki narodowo-edukacyjne, trudno rozstrzygnąć. Niewątpliwie prawomocna decyzja odnośnie ich powołania, czyli wspomniany dekret z 1794 r. przyspieszył proces porządkowania przejętych księgozbiorów.

Autorem jednego z bardziej interesujących pomysłów tamtych czasów był Anne-Louis-François de Paule Le Fèvre d'Ormesson de Noyseau (brat wspomnianego wyżej markiza d'Ormesson'a), odpowiedzialny za dawną Bibliotekę Królewską, zaliczany w poczet pierwszych dyrektorów nowożytnej Biblioteki Narodowej Francji ${ }^{42}$. W celu jak najbardziej racjonalnego i pełnego uzupełnienia zbiorów tworzonej na rojalistycznych fundamentach nowej, bo obywatelskiej Biblioteki Narodowej, zainicjował on prace nad utworzeniem i publikacją jednego, centralnego katalogu wszystkich depozytów Francji ${ }^{43}$. Co więcej, wyliczył, że owa karkołomna operacja całościowego skatalogowania wszystkich księgozbiorów istniejących w jego ojczyźnie będzie kosztować 15-18 000 liwrów, praca potrwa pięć lat, a ów pierwszy w świecie, centralny katalog państwowy zostanie ostatecznie opublikowany w 50 tomach in folio. Wobec powyższego, Commission des monuments, ażeby ułatwić pracę na prowincji, zdecydowała, że wszystkie kolekcje departamentalne będą

${ }^{41}$ Ojcowie francuskiego, publicznego bibliotekarstwa, z J.-M. Coupé, Dom Poirier czy Henri Grégoire na czele, robili wszystko, ażeby chronić ów narodowy majątek: czy to koordynując pracę i wzmacniając nadzór nad składnicami w prowincjach (Coupé), czy to uświadamiając w swoich rozlicznych raportach wyjątkową wartość i znaczenie średniowiecznych manuskryptów, rozproszonych po wszystkich pokościelnych depozytach Francji (Poirier), czy wreszcie ujawniając, gromiąc i zmuszając najwyższe władze rewolucji do walki z wandalizmem i głupotą skierowaną wobec wspólnego, kulturowego dziedzictwa (Grégoire). Więcej na ten temat zob: A. Masson, P. Salvan, Les bibliothèques..., s. 50-51; M. Wierzbicka, Biblioteki publiczne..., s. 12.

${ }^{42}$ Les directeurs de la Bibliothèque nationale. Les maîtres de la librairie, administrateurs généraux, présidents, Bibliothèque Nationale de France 2004, s. 4-5 - http://www. bnf.fr/documents/administrateurs.pdf [24 XII 2012].

${ }^{43}$ D. Palliers, Les bibliothèques..., s. 36. 
porządkowane i inwentaryzowane według ujednoliconego, nieco uproszczonego schematu, a następnie wysyłane do Paryża i scalane w ów wspólny katalog centralny. Ówcześni bibliotekarze-erudyci zdawali sobie sprawę z niebywałych rozmiarów całego przedsięwzięcia, wobec czego powołano do pomocy Biuro do Spraw Bibliografii (Bureau de bibliographie), którego celem, jak pisał jego pierwszy przewodniczący - dziennikarz i znany francuski językoznawca - François-Urbain Domergue, było również zdobycie wiedzy na temat skarbów literatury narodowej i zapewnienie tymże uczciwej repartycji po wszystkich ważnych bibliotekach Francji ${ }^{44}$. Troska o uczciwy rozdział najcenniejszych woluminów była w tamtych czasach bardzo istotna, gdyż bibliotekarze spoza stolicy bali się ponownych konfiskat lokalnych, jako tako już uporządkowanych depozytów, tym razem na rzecz Paryża i jego wielkich bibliotek. Narodowa inwentaryzacja ponad dwunastu milionów skonfiskowanych woluminów, zdeponowanych na terenie całej Francji, wydaje się być, z naszego, jak i ówczesnego, punktu widzenia, rzeczą niemożliwą. Tym bardziej, że młoda Republika była nękana zarówno groźbą interwencji zewnętrznej, rebeliami wewnątrzpaństwowymi, spiskami i mnóstwem problemów natury administracyjno-politycznej i ekonomicznej. Pomimo tych wszystkich niedogodności, nad ową narodową bibliografią pracowano aż do 1796 r., kiedy to ówczesny minister spraw wewnętrznych Pierre Bénézech wydał decyzję o zaniechaniu dalszych działań nad centralnym katalogiem Wielkiej Rewolucji z braku środków finansowych i odpowiednio przeszkolonych kadr ${ }^{45}$.

Interesującym wydaje się też być pomysł samego procesu tworzenia owego katalogu z punktu widzenia organizacyjno-logistycznego. Jak wspominano wyżej, poszczególne dystrykty zobowiązano do sporządzenia spisów książek skonfiskowanych, które następnie były wysyłane do Commission des monuments, tam wnikliwie studiowane pod kątem wartości i przydatności. Odsyłany z powrotem władzom lokalnym ów pierwotny katalog zawierał szczegółowe instrukcje odnośnie dalszych działań. Warto w tym miejscu podkreślić, że jednym z ważnych celów, obok już kilkukrotnie wzmiankowanego przejęcia francuskiego dziedzictwa narodowego na rzecz państwa był ten mówiący o czystkach w ramach samych księgozbiorów. Nawet sam wielki Domergue zachęcał do palenia ksiąg „zgubnych”, o treści teologicznej, mistycznej, dotyczących władzy

${ }^{44}$ W. Busse, F. Dougnac, François-Urbain Domergue. Le grammairien patriote (17451810), Tubingen 1992.

${ }^{45}$ P. Riberette, De la Commission des monuments au Conseil..., s. 56. 
królów, czy tych na temat systemu feudalnego i legislacji z czasów ancien régime'u. Można wprawdzie zachować, według jego dodatkowych zaleceń, po jednym lub dwóch egzemplarzach takich pozycji dla potomnych - ,jako świadectw historycznych czy też swego rodzaju kuriozów naszych czasów", ale nawet on wcale nie był przekonany, czy rzeczywiście warto to robic ${ }^{46}$. Jeśli idzie o dublety, poszczególne depozyty miały się nimi wymieniać lub organizować publiczne wyprzedaże. W niektórych regionach tak wyselekcjonowane pozycje sprzedawano na wagę. Średnio płacono 8 liwrów od kwintala zbędnych książek, nie zważając na ich realną wartośćc ${ }^{47}$.

Wydaje się jednak, że ducha tamtych czasów najbardziej oddawała akcja sporządzania samych kart katalogowych. Detaliczne instrukcje nadsyłane z Paryża udzielały dokładnych informacji, w jaki sposób sporządzać opis bibliograficzny, co nieodzownie powinno się w nim znaleźć, a co można pominąć. Instrukcje zwracały uwagę na podanie proweniencji jednostki, zachowanie alfabetycznego układu, etc., oraz zalecały wykorzystanie do sporządzania owych katalogowych fiszek, z braku odpowiedniej ilości kartonu, znienawidzonych przez rewolucję kart do gry w wista, symbolu próżności stanów uprzywilejowanych. Ponadto sugerowano, ażeby do długich opisów bibliograficznych używać asów, gdyż miały więcej pustego miejsca. I tak, oto król, dama, walet czy dziewiątka, nieważne - pik, kier czy karo, posłużyły rozwojowi francuskiego bibliotekarstwa publicznego. Wprawdzie zdarzało się, że kart do gry brakowało i wówczas ślepo posłuszni nowym władzom urzędnicy, brali pierwsze lepsze, bardziej solidne pod względem jakości papieru woluminy, wyrywali grubsze kartki, pięknie przycinali do wielkości owych pokerowych kart i wypisywali według instrukcji: tytuł, autora, proweniencję etc. W okresie 1789-1799 sporządzono w ten sposób ok. 1,4 miliona fiszek $^{48}$.

9 lutego 1792 r., o czym wspominano wyżej, państwo przejęło dobra emigrantów. 30 marca wydało rozkaz sporządzenia inwentarzy pozostawionych dóbr ruchomych, a we wrześniu ostatecznie zdecydowano o ich konfiskacie i sprzedaży na rzecz „obywatelskiego narodu”. Tymczasem do głosu doszło radykalne skrzydło rewolucji z Maximilien François Ma-

\footnotetext{
${ }^{46}$ G. K. Barnett, Histoire des bibliothèques..., s. 23.

47 A. Masson, P. Salvan, Les bibliothèques, Paris 1961, s. 38.

${ }^{48}$ K. Maleczyńska, Zarys historii..., s. 71.
} 
rie de Robespierrem i Georges Dantonem na czele. Wydawałoby się, że w ferworze walki, przejmowania władzy przez jakobinów, wprowadzania polityki terroru, w czasach przeraźliwego głodu, wypowiedzenia przez Francję wojny Austrii etc., nikt nie będzie zajmować się książkami ${ }^{49}$. Tymczasem było wręcz odwrotnie.

Niewątpliwie do uświadomienia wyjątkowego znaczenia prywatnych kolekcji przyczyniła się w pewnym sensie właśnie agresywna polityka jakobinów, którzy nie gdzie indziej jak w szlacheckich i mieszczańskich bibliotekach szukali specjalistycznych map i planów strategicznych, podręczników musztry, opisów broni etc., ażeby skutecznie, a przynajmniej lepiej od dotychczas rządzących żyrondystów, stawić czoła wewnętrznemu i zewnętrznemu wrogowi. Niestety, część z tych bardziej wartościowych publikacji, ich dawni właściciele zdążyli wywieźć za granicę, część zaś została schowana lub rozkradziona. Zbyt późno, bo dopiero 9 października 1793 r., wycofano się też z dekretu zezwalającego na dowolną sprzedaż i celowe niszczenie prywatnych księgozbiorów, zwłaszcza tych zaopatrzonych $\mathrm{w}$ arystokratyczne herby i inne symbole znienawidzonej monarchii i feudalizmu. Za późno uświadomiono sobie bardziej praktyczne, niż li tylko ideologiczne znaczenie, poważnej części zdewastowanych poszlacheckich ksiegozbiorów. Ultraradykałowie, zgromadzeni wokół Jacquesa Héberta, redaktora skrajnie lewicowej gazety Le Père Duchesne, bez żadnych skrupułów, ale w szczerze jakobińskim duchu, jeszcze na początku 1793 r. urządzali w Paryżu i na prowincji spektakularne akcje palenia elitarnych bibliotek, dewastację kościolów i wszystkich zabytków, kojarzonych ze starym porządkiem ${ }^{50}$.

W czasach, kiedy dogmaty religii katolickiej zostały zastąpione Kultem Rozumu, a katedra Notre-Dame przemianowana na Świątynię Rozumu, należało się spodziewać otrzeźwienia i bardziej zdroworozsądkowego podejścia do dóbr kultury. W tym też duchu, już 13 kwietnia 1793 r., Konwent Narodowy wydał dekret, który wymierzał karę dwóch lat więzienia dla każdego, kto przyczyni się do zniszczenia jakiegokolwiek dzieła sztuki narodowej. Zgodnie z kalendarzem rewolucji, odrębny zapis prawny z 3 brumaire Roku II (24 października 1793 r.) stanowczo zabraniał dewastacji książek z prywatnych kolekcji, nawet jeśli byłyby one opatrzone znienawidzonymi herbami szlacheckimi. Kolejny akt doprecyzowywał, że zabronione jest również wyrywanie pojedynczych, a nawet

${ }^{49}$ J. Baszkiewicz, Historia Francji, Wrocław 1974, s. 420-444.

${ }^{50}$ G. Lefebre, Ch. H. Pouthas, M. Baumont, Historia Francji, Warszawa 1969, t. II, s. $78-79$. 
fragmentów kart, czy zamazywanie tych ze znakami proweniencyjny$\mathrm{mi}^{51}$. W tym samym okresie, w drugiej połowie 1793 r., została oficjalnie otwarta pierwsza wielka biblioteka publiczna Paryża - Biblioteka Muzeum Historii Naturalnej, a wspomnianemu sekwestrowi wszelkich dóbr po przedrewolucyjnych akademiach i towarzystwach naukowych (lipiec 1793 r.), towarzyszyło publiczne obwieszczenie przestrzegające obywateli przed aktami potencjalnego wandalizmu, który należy tępić, szczególnie ów wobec sztuki i książki, które od teraz są wszak własnością całego narodu.

W celu skuteczniejszego przejęcia, dozoru i inwentaryzacji znacjonalizowanego, tym razem naukowego, dziedzictwa, na miejsce Commission des monuments, powołano bardziej wyspecjalizowaną Tymczasową Komisję ds. Sztuk (Commission temporaire des arts) ${ }^{52}$. Wydaje się, że ta kolejna administracyjna komórka, odpowiedzialna za kolejno konfiskowane biblioteki i ich zbiory, nie tylko skupiała większą liczbę fachowców z różnych dziedzin, ale była też lepiej zorganizowana wewnętrznie (w jej skład wchodziło trzynaście specjalistycznych sekcji, m.in. do spraw historii naturalnej, anatomii i medycyny, oraz bibliografii), a jej obrady odbywały się w miarę regularnie. Ponadto przejawiała wyjątkową aktywność nie tylko w stolicy, ale również w terenie. Cały rok 1794, to żmudne wizytacje depozytów regionalnych, wyznaczanie im lepszych siedzib, lepszych warunków przechowywania i gromadzenia, ale i walka ze szczurami, wilgocią i głupotą ludzką o lepsze miejsce dla książki, w dosłownym i przenośnym tego słowa znaczeniu. $Z$ drugiej strony Komisja próbowała odzyskać to, co rozkradziono, nie wahając się przed rewizjami po domach prywatnych i konfiskatami nieprawnie zagrabionych dzieł, wzmagając kontrole graniczne, nakładając surowe kary za nieprzestrzeganie zaleceń inwentaryzacyjno-katalogowych w samych bibliotekach i depozytach, etc. Kilkudziesięciu komisarzy było zgodnych, co do tego, że najważniejszą sprawą dla ich nowego państwa będzie, obok ochrony literackiego dziedzictwa narodowego Francji, wykształcenie nowych, światłych obywateli w oparciu o źródła pozyskane od klas uprzywilejowanych. Wobec tego trzeba je ratować przed kompletną dewastacją. Owe uratowane z rewolucyjnej pożogi tysiące woluminów, a raczej wyselekcjonowaną ich część, należało oddać do dyspozycji ludu zasilając tym samym sieć rozrastających się powoli narodowych bibliotek publicznych, ale także pomyśleć o przeznaczeniu części z nich na rzecz nowych, „rewolucyj-

${ }^{51}$ H. Richard, Des bibliothequèques des districts..., s. 56.

${ }^{52}$ G. K. Barnett, Histoire des bibliothèques..., s. 30 . 
nych" szkół, wszak winny one mieć stosowne zaplecze ideologiczne, tj. właściwie dobrany księgozbiór. Rzecz dziwna, a może symptomatyczna, ci którzy przyczynili się do zgilotynowania ok. 17 tys. Francuzów, co najmniej tyle samo, jeśli nie więcej książek uratowali przed okrucieństwem jakobińskiego wandalizmu ${ }^{53}$.

Wielka Rewolucja Francuska, jako pierwsza w Europie, wyartykułowała i umocniła wiarę w potrzebę tzw. pedagogiki uniwersalnej, skierowanej do ludu, która miała być szerzona nie tyle przez powszechne szkoły, z zakładaniem których był wielki kłopot (brak nauczycieli, kadr, programów i wszelkich pomocy naukowych), ile poprzez publiczne biblioteki. W 1790 r., w jednym ze swoich pism obywatel Tuet, dawny kanonik z miasteczka Sens, wspominając o już upublicznionych bibliotekach Paryża, domagał się w imieniu Stanu Trzeciego powołania identycznie działających książnic również na prowincji w celu rozbudzenia obywatelskiej świadomości ludu, gdyż „nareszcie nadszedł czas zaspokojenia pragnienia wiedzy" ${ }^{54}$. W podobnym duchu wypowiadało się wielu innych myślicieli, na czele ze słynnym filozofem, matematykiem Nicolas de Condorcet $^{55}$. Owe nowopowstające rewolucyjne biblioteki, czyli, jak je pięknie nazwał ojciec Grégoire, ateliers myśli ludzkiej ${ }^{56}$, miały oświecać wszystkich uczciwych obywateli Francji ${ }^{57}$. W nowych, tworzonych przez rewolucję instytucjach tego typu obywatel będzie mógł posiąść „racjonalną wiedzę” i rozwinąć „ducha rozumu”58. Retoryka tego rodzaju towarzyszyła zarówno jakobinom, jak i kolejnym, bardziej umiarkowanym rządom termidorian ${ }^{59}$.

${ }^{53}$ B. Baczko, Rewolucja, wtadza, nadzieje, rozterki, Gdańsk 2010, s. 100 nn.

${ }^{54}$ H. Richard, Des bibliothequèques des districts..., s. 43.

${ }^{55}$ Do 1790 r. Condorcet opublikował na łamach czasopisma La bibliothèque de l'homme public cztery traktaty naukowe promujące powszechną edukacje na rzecz lepszego, nowego państwa. Więcej zob.: B. Jolibert, Condorcet (1743-1794), „Perspectives: revue trimestrielle d'éducation comparée", 23:1993, n 1-2, s. 201-213.

${ }^{56}$ Henri Jean-Baptiste Grégoire, zwany ojcem Grégoire z powodu uzyskanych przed Rewolucją święceń kapłańskich, był jednym z jej najaktywniejszych działaczy na polu ksiażki i nauki, m.in. pomysłodawcą-fundatorem Narodowego Konserwatorium Sztuk i Rzemiosł (Conservatoire national des arts et métier), Instytutu Francuskiego (Institut de France) i wielu innych.

57 G. K. Barnett, Histoire des bibliothèques..., s. 36-40.

58 J. Guilhaumou, La langue politique et la Révolution française, Paris 1989, passim.

${ }^{59}$ F.-A. Aulard, Talleyrand-Périgord, Institute Nationale de Recherches Pédagogiques 2010 - http://www.inrp.fr/edition-electronique/lodel/dictionnaire-ferdinand-buisson/document.php?id=3716 [24 XII 2012]. 
Okres rewolucji francuskiej, z punktu widzenia przyspieszenia rozwoju tzw. obywatelskiej oświaty, doczekał się wielu pozytywnych ocen ${ }^{60}$. Jak już kilkakrotnie podkreślano, ów walor wychowawczo-edukacyjny pokładany w bibliotekach stanowił jedną z istotniejszych przyczyn owego masowego przyzwolenia (a nawet żądania) na ich upublicznienie. Znawcy tematu wyraźnie podkreślają ważność księgozbiorów w świadomości władz rewolucyjnych, dla rozwoju powszechnej edukacji i wykształcenia przyszłego, lepszego społeczeństwa Francuzów ${ }^{61}$.

Po dokonaniu kolejnych zmian na administracyjnej mapie Francji, w ramach odgórnego planu reorganizacji tzw. instytucji użyteczności publicznej, do których zaliczano m.in. biblioteki i inne placówki oświatowe, 25 października 1795 r. Konwent Narodowy wydał specjalny dekret, który nakazywał założenie tzw. szkół centralnych w każdym departamencie, a w ich strukturach obowiązkowe powołanie nowego typu bibliotek publicznych. Miały one skompletować swoje zasoby zagarniając resztki książek, pozostałych w niewyczerpanych jeszcze pobliskich depozytach, a w razie braku stosownej literatury, wnosić petycje do Ministra Spraw Wewnętrznych o rządowe uzupełnienie zbiorów. Ponadto, w 1797 r. została sporządzona ostateczna lista komun (nowa podstawowa jednostka podziału administracyjnego), w których, z braku szkół centralnych, wydaje się być konieczne, na bazie dotychczasowych składnic - owych dépôts littéraires stworzenie kolejnego rodzaju publicznych książnic dla oświecania ludu.

Powróćmy raz jeszcze do nowego typu szkół, tzw. centralnych, do których przez sześć lat miała uczęszczać młodzież, począwszy od jedenastego roku życia. Obowiązkowe tworzenie w ich strukturach bibliotek był bodajże pierwszą w świecie, udaną próbą, powołania do życia sieci bibliotek publiczno-szkolnych, gdyż państwowe instrukcje wyraźnie mówiły, że zadaniem tej nowej instytucji nie jest wyłącznie dbanie o potrzeby personelu szkoły i uczniów, ale w równej mierze ma ona troszczyć się o społeczność lokalną. Ma być otwarta w dogodnych dla niej dniach i godzinach. Co więcej, prawodawcy rekomendowali dobór literatury stosownie do miejscowych potrzeb (sic), jeśli np. biblioteka położona jest $\mathrm{w}$ rejonie nadmorskim preferowana niechże będzie literatura marynistyczna ${ }^{62}$, etc. Ażeby wyjść naprzeciw tzw. grand public w specjalnie

${ }^{60}$ F. Mayeur, Histoire de l'enseignement et de l'éducation 1789-1930, Paris 2004, passim.

61 Tymczasem kolejny okres w historii Francji, tzw. Restauracji można uznać w tym względzie za swego rodzaju regres, powrót do idei biblioteki służącej przede wszystkim rozwojowi nauki, a nie oświaty.

${ }^{62} \mathrm{~Np}$. instrukcje dla biblioteki w Rochefort, zob.: H. Richard, Des bibliothequèques des districts..., s. 53. 
spisywanych i rozsyłanych na prowincje instrukcjach zalecano posiadanie w nowych bibliotekach nie tylko poważnej literatury klasycznej, ale też książek podróżniczych, lekkiej poezji, a nawet dobrze napisanych romansów ${ }^{63}$. „Trzeba się tylko zatroszczyć, ażeby nie było żadnych bezeceństw raniących obyczaje" ${ }^{64}$.

Biblioteki szkół centralnych były bardzo starannie zorganizowane. Większość z nich posiadała kompletne katalogi, listy pozycji brakujących, niezbędnych w procesie nauczania, wewnętrzne regulaminy, które określały dni i godziny ich otwarcia, zasady korzystania z księgozbioru i z katalogów, opisywały również właściwe zachowanie w bibliotece (lekturę w ciszy i spokój, zakaz samodzielnego wyszukiwania i brania z półek dzieł, etc. ${ }^{65}$. Zadbano również o stosowny prestiż i pozycję personelu bibliotecznego, który był wybierany i rekomendowany przez lokalne władze, zatwierdzany i nominowany na poziomie departamentalnym i przysługiwały mu taki sam status i pensja, jaką posiadało grono profesorskie szkół centralnych. Tak więc po raz pierwszy bibliotekarz został zaliczony w poczet państwowej służby cywilnej Francji.

Pięć lat później, już za czasów Napoleona Bonaparte, szkoły centralne zostały zastąpione przez istniejące do dziś licea, a ich księgozbiory, przekazane do dyspozycji władz miejskich, zasiliły tamtejsze, już w pełni ukonstytuowane biblioteki. Niestety, zbyt szybki bieg francuskiej historii przekreślał czasami i te najbardziej postępowe zdobycze rewolucji (jak np. owe szkoły centralne wraz z ich książnicami) w imię nowej ideologii, tym razem bibliotekarstwa i szkolnictwa na usługach wielkiego cesarza.

$*$

Wprawdzie, w części publikacji, za symboliczną datę początku francuskiego bibliotekarstwa publicznego przyjęło się uznawać 27 stycznia 1794 r., w innych natomiast 28 stycznia 1803 r., kiedy to właśnie owe biblioteki szkół centralnych przeszły na własność miast, to jednak prawdziwie rewolucyjnym w tej mierze wydaje się być, ów pierwszy, wcześniej omówiony dekret, uchwalający powołanie w każdym dystrykcie, co najmniej jednej biblioteki publicznej, która miała zapewnione stosownie uzupełniane zbiory (art. 1, 5, 12), lokal (art. 2, 13), państwową opiekę $\left(\right.$ art. 8, 9) i lokalną administrację art. $(2,3)^{66}$.

63 Tamże, s. 50.

${ }^{64}$ G. K. Barnett, Histoire des bibliothèques..., s.51.

65 Zob.: przykładowy regulamin szkoły centralnej w Besançon (1795-1802), zamieszczony [w:] H. Richard, Des bibliothequèques des districts..., s. 51.

${ }^{66}$ Cały tekst ustawy, zob: Décret du 8 pluviôse an II (27 janvier 1794) établissant des bibliothèques de district, [w:] G. K. Barnett, Histoire des bibliothèques..., s. 415, 416. 
O to, ażeby biblioteki publiczne, obok nowo powstających szkół, stały na straży wychowania narodowego zabiegali wszyscy najwięksi myśliciele tamtej epoki. Skoro rewolucja wprowadziła równość wobec prawa, wolność słowa i wyznania, ,zamknęła salony, które od dwóch wieków sprawowały nad literaturą władzę najwyższą i nieograniczoną, (...)", skoro w jej duchu, na masową skalę „zjawiła się nowa potęga - prasa, która dostarczała gotowych poglądów niewyrobionym czytelnikom" 67 , skoro wraz z nadejściem nowej epoki, forsowano w zakresie powszechnej edukacji, organizację szkolnictwa publicznego „wspólnego dla wszystkich oraz bezpłatnego w tych częściach nauki, które są nieodzowne dla każdego" ${ }^{68}$, tym bardziej starania i zabiegi o otwarte, obywatelskie czytelnie i biblioteki były uzasadnione i stały na szczycie hierarchii nowych potrzeb narodowych Francji.

Z zawieruchy końca XVIII w. najbardziej umocnione wyszły książnice paryskie. Dawna Biblioteka Królewska, teraz Narodowa, w roku 1800 podwoiła swój stan posiadania w stosunku do roku 1789. Biblioteka Arsenału - dawniej książnica zbiegłego za granicę hrabiego Artois, przyszłego króla Francji Karola X (1824-1830) - szczególnie wzbogaciła się na depozytach poemigracyjnych. Szacowna biblioteka Sainte-Genevieve, wówczas zwana była biblioteką Panteonu; jej zasób został odziedziczony po bibliotece Collège des Quatre-Nations, stworzonej jeszcze przez Mazariniego. Do tej liczby włączyć także należy bibliotekę Zgromadzenia Narodowego, bibliotekę Muzeum Historii Naturalnej oraz wiele innych ${ }^{69}$.

Niewątpliwie prace Commission temporaire des arts, zwłaszcza owa karkołomna, podjęta na niespotykaną dotąd skalę próba stworzenia centralnego katalogu narodowego, a następnie poczynione na rzecz bibliotek publicznych zapisy prawne $\mathrm{z}$ lat dziewięćdziesiątych, na czele z decyzją Konwentu z 27 stycznia 1794 r., stworzyły silne podwaliny współczesnego bibliotekarstwa francuskiego. W sumie w owym bardzo ważnym 1794 roku powołano do życia aż 600 nowych książnic ${ }^{70}$, a każda z nich miała być kuźnią lepszych i mądrzejszych obywateli budujących doskonalszy kraj w oparciu o jego narodowe, częściowo już zweryfikowane i skatalogowane dziedzictwo literackie.

${ }^{67}$ G. Lanson, P. Tuffrau, Historia literatury francuskiej..., s. 413.

68 J. Draus, R. Terlecki, Historia wychowania, wiek XIX i XX, Kraków 2009, t. II, s. 17.

${ }^{69}$ Pełniejszy opis sytuacji bibliotek paryskich w trakcie i po rewolucji, zob.: T. Charmasson, C. Gariello, Les grandes bibliothèques parisiennes, oraz S. Balaye, La Bibliothèque nationale pendant la Révolution, [w:] Histoire des bibliothèques françaises..., s. 61-84.

${ }^{70}$ D. Palliers, Les bibliotheques..., s. 40. 
Być może na dalekiej francuskiej prowincji było jeszcze za wcześnie na tego typu prekursorskie działania (przymusowe konfiskaty i przemianowywania dawnych prywatnych bibliotek na państwowe, powoływanie kolejnych, etc.) jakie z powodzeniem przeprowadzały wielkie miasta Francji, na czele z Paryżem. Niemniej jednak przysłowiowy kamień węgielny został na trwałe wkopany, dzięki czemu dzisiaj i te najmniejsze, prowincjonalne biblioteki publiczne mogą, w sporej części, pochwalić się bogatą tradycją i rewolucyjną proweniencją, a wytrwali poszukiwacze odnaleźć skarby francuskiej literatury sprzed $1789 \mathrm{r}$.

Ponad dziesięć rewolucyjnych lat w dziejach bibliotekarstwa francuskiego, a także europejskiego, to niebywały przyrost różnorodnych pomysłów i nie zawsze trafnych inicjatyw, to niespotykane przyspieszenie na drodze ich rozwoju, to prawdziwe i chyba pomimo wszystko z sukcesem podjęte przez same biblioteki wyzwanie, z którego rewolucyjnym dziedzictwem przyjdzie im się dopiero zmierzyć i je utrwalić w kolejnych latach: po wojnach napoleońskich, w czasach restauracji Burbonów, Monarchii Lipcowej i II Republiki. Ale lata 1789-1803 to także czas strat. Dziesięć do dwunastu milionów wszelkiego rodzaju rękopisów, starodruków, dokumentów, woluminów ${ }^{71}$ zostało bezpowrotnie zniszczone, spalone, rozgrabione, jednym słowem na zawsze utracone dla francuskiej kultury i jej piśmiennego dziedzictwa narodowego.

\section{Streszczenie}

\section{Początki bibliotekarstwa publicznego we Francji i świadomości ochrony narodowego dziedzictwa kulturowego a Wielka Rewolucja 1789-1799}

Artykuł przedstawia próbę zorganizowania publicznego bibliotekarstwa we Francji okresu Wielkiej Rewolucji, ukazując przy tym jego ważność w procesie kształtowania nowego obywatela. We wstępie zwrócono uwagę na pierwsze, bardziej lub mniej udane, próby otwierania różnego typu bibliotek jeszcze przed 1789 r. Zasadnicza część tekstu dotyczy nacjonalizacji księgozbiorów kościelnych, prywatnychszlacheckich oraz naukowych, a także związanych z tym oczekiwań i kłopotów. Opisane zostały zarówno pionierskie próby stworzenia sieci ludowych bibliotek we Francji na bazie tzw. dépôts litéraires, zasygnalizowane przekształcenia wielkich książnic Paryża, w tym biblioteki królewskiej, w nowe typy instytucji służących narodowi. Zwrócono uwagę na pierwsze w świecie próby stworzenia katalogu centralnego.

${ }^{71}$ L.X. Polastron, Livres en Feu. Histoire de la destruction sans fin des bibliothèques, Paris 2004, s. 196. 
Próbowano, trzymając się chronologii Rewolucji, ukazać kształtowanie się i ważność takich pojęć jak: dziedzictwo narodowe i edukacja obywatelska poprzez pryzmat działalności pierwszej sieci bibliotek publicznych Francji.

\section{Summary}

\section{The Beginnings of Public Libraries in France and the Emergence of Conscious Need to Preserve National Cultural Heritage vis-à-vis the Great Revolution, 1789-1799}

The article considers the attempt at organizing a network of public libraries in France during the Revolution, and the influence of this process on the mind of the new citizen. I. Pugacewicz begins with earlier efforts at opening such libraries, already before 1789. Then she discusses the nationalization of Church book collections, private libraries of the aristocracy, and the collections of learned institutions. Special attention is paid to the expectations linked with these actions and to the problems which arose during their execution. On the basis of the books deposited in the so called dépôts litéraires, alongside the establishing of great book-repositories in Paris, such as the reorganisation of the Royal Library into the Bibliothèque nationale, which ever since were to serve the nation, the revolutionary authorities also tried to set up a network of popular libraries throughout the country. Another important initiative was the attempt at creating the first in history national union catalogue. The author also follows synchronizing her observations with the chronological order of political events and with the activities of the first French network of public libraries the emergence of such concepts as national heritage and civic education. 